Resumen por los autores, John A. Detlefsen y Elmer Roberts, Illinois Agricultural Experiment Station.

Estudios sobre el crossing over.

I. El efecto de la selección sobre los valores del crossing over.

El tanto por ciento de cross overs de la combinación de ojos blancos y ala en miniatura de Drosophila melanogaster es próximamente 33, y la "distancia de mapa" hallada por Morgan y Bridges es proximamente 36 . La selección de hembras que presentaban valores bajos en el crossing over redujo el tanto por ciento de estos últimos casi a $\mathrm{O}$ en la serie $\mathrm{A}$ y su derivada serie $A^{\prime}$. Estas dos series reprodujeron este valor reducido del crossing over durante tres y nueve generaciones, respectivamente. En otra serie independiente B, el valor del crossing over se redujo a 5 o 6 por ciento en 28 generaciones y el tronco seleccionado ha continuado produciendo dicho crossing over, sin más selección, durante 22 generaciones. La serie C, con crossing over alto, no produjo por selección un aumento en los valores de crossing over, pero produjo en la $\mathrm{F}$, nueve pares que sumaban 26 cross overs; 1055 individuos -2.46 por ciento de crossing over.

El crossing over es por consiguiente muy variable y manifiesta los efectos de la selección. La selección de valores bajos ha

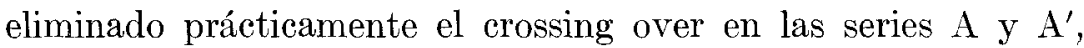
y le ha reducido considerablemente en al serie B. La selección de un valor elevado no ha aumentado los valores de crossing over en la serie $\mathrm{C}$, pero probablemente ha producido más crossing over doble en algunas hembras, que resulta en una disminución del valor de dicho proceso con relación a los dos genes escojidos. Los autores proponen varias hipótesis, pero parece sumamente probable que los factores múltiples regulan o por lo menos influyen considerablemente sobre el crossing over. Si esta explicación es correcta, debemos modificar nuestra opinión sobre el crossing over en relación a las distancias que separan a los genes.

Translation by José F. Nonidez

Cornell Medical College, New York 


\title{
STUDIES ON CROSSING OVER
}

\author{
I. THE EFFECT OF SELECTION ON CROSSOVER VALUES ${ }^{1}$
}

\section{J. $\Lambda$ DETLEFSEN AND E. ROBERTS ${ }^{2}$}

TWO TEXT FIGURES

CONTENTS

Introduction $\ldots \ldots \ldots \ldots \ldots \ldots \ldots \ldots \ldots \ldots \ldots \ldots \ldots \ldots \ldots \ldots \ldots \ldots \ldots$

Materials and methods . . . . . . . . . . . . . . . . . . . . . . . 335

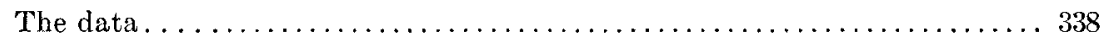

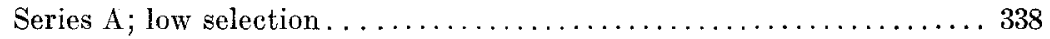

Series $\mathrm{A}^{\prime}$; low selection; derived from series $\mathrm{A} \ldots \ldots \ldots \ldots \ldots \ldots \ldots \ldots 34$

Series B; low selection . . . . . . . . . . . . . . . . . . . . . . . 343

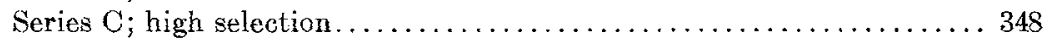

Discussion and surnmary . . . . . . . . . . . . . . . . . . . . . . 349

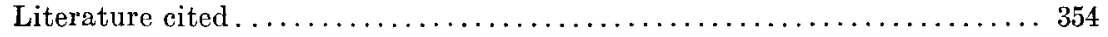

\section{INTRODUCTION}

The experiments described in this paper were undertaken in an effort to answer the question: can the percentage of crossing over be modified by selection. The significance of an answer (either affirmative or negative) and its relation to our present concepts on crossing over, locus, chromosome mapping, etc., were apparent and seemed to justify the time and attention necessary to carry these investigations over so long a period. They were planned and begun in February, 1916, and have involved the classification of over 300,000 individuals. Had the results been negative, the experiment would have been

1 Paper no. 12, from the Laboratory of Genetics, Illinois Agricultural Experiment Station.

2 We wish to give credit to the following graduate students for aid in these investigations: Mr. A. T. Fishman carried series A for three generations; Mr. L. E. Thorne carried series $\mathrm{C}$ for seven generations. The war called both men from their work. The late Prof. B. O. Severson carried series B from the beginning to the $\mathrm{F}_{14}$ generation. In the death of Professor Severson both genetics and scientific agriculture have lost a capable and enthusiastic student and investigator. 
dropped much earlier, but the effects of selection were conspicuous and prompted us to carry the experiments through to their logical end.

Whenever one crosses an individual with the linked factors, $A B$, to the double recessive, ab, then the heterozygote, $A B a b$, will form four sorts of gametes: $A B+a b$, the parental types, and $\mathrm{aB}+\mathrm{Ab}$, the recombinations or crossovers. The relative frequencies of these gametes will depend upon the distance between the loci for A and B, at least according to the commonly accepted hypothesis. If a distance on the chromosome, which gives 1 per cent of crossovers is adopted as an arbitrary unit, then the distance between genes on a chromosome may be determined in terms of this arbitrary unit, and the map of a chromosome may be plotted, as has been done by investigators working with Drosophila. Repeated trials using large numbers, with comparable stocks and controlled environmental conditions, have shown that the ratio of crossovers to total gametes is uniform enough to suggest that the distance between two genes is fairly constant. However, the phenomenon of crossing over is not as simple as was first supposed, for a number of genetic and environmental influences have been found to affect crossing over markedly, at least in Drosophila melanogaster. Bridges ('15) stated that crossing over varied with age, for second broods showed a rather consistent decrease. Plough ('17) found that low and high temperatures (below $17.5^{\circ} \mathrm{C}$., and above $28^{\circ} \mathrm{C}$.) increase the amount of crossing over. Sturtevant ('19) found in the second chromosome of Drosophila one gene to the left of purple and one to the right, both of which lower the percentage of crossing over in that portion of the chromosome in which they. lie. He also found a similar factor in the third chromosome. Furthermore, an incompletely investigated case disclosed a dominant third chromosome gene which increased the amount of crossing over between purple and curved in the second chromosome. Gowen ('19) measured the amount of variability shown in a population of 240 Drosophila females with respect to crossing over between fixed points in the third chromosomes and found a very high degree of variability. His data show that 
a change in genes between two or more fixed points may be accompanied by a slight disturbance of the crossing-over ratios between these fixed points. Sex, to be sure, has a striking effect on crossing over, for the male Drosophila does not show this phenomenon even in the autosomes.

Whenever one observes a large number of Drosophila females of the generalized zygotic formula $\frac{A \quad B}{a}$, it is common to find much variability with respect to the amount of crossing over, even though the cultures are kept at the usual normal temperature and no striking genetic modifiers of crossing over are known to exist. Just what this variability is due to is not known. Some of it may represent fluctuations of sampling and some of it may be due to age, but very frequently the deviations are so wide as to arouse a suspicion that hitherto unknown causes may be effective. If this variability is due, at least in part, to genetic causes, then selection should have an effect, particularly if environmental fluctuations do not mask or obliterate the effect of genetic modifiers. It was with this thought in mind that the senior writer began to select for high and low crossover values.

\section{MATERIALS AND METHODS}

The selection experiments consisted of four series: Series A, low selection; Series $A^{\prime}$, derived from series $A$ in $F_{7}$;

Series $B$, low selection, a second experiment duplicating series A; Series C, high selection.

Each series began with a single white-eyed miniature-winged female mated to a wild red long male. These strains were chosen because the characters are easily recognized, show little or no variability, and have at least fair viability. To classify any female with respect to her 'crossover capacity' requires the classification of all the progeny which we can obtain from her. Thus in $F_{6}$, series A (table 1), we classified 8660 offspring to obtain the necessary data on fifty-six $F_{5}$ females for the purpose of selection. In the usual selection experiment, individuals are 
chosen on the basis of external characters which can be determined by direct observation. To select for high and low crossover values is rather more tedious and time exacting because the individual cannot be classified directly with respect to its crossover potentiality. Its character is disclosed only after obtaining a reasonably large progeny. Characters which could be recognized easily and classified rapidly and accurately were indispensable. The two allelomorphic pairs, white eye vs. red eye, and miniature wing vs. long wing seemed to fulfill these conditions, and they have the added advantage of giving a large, initial, normal percentage of crossovers (about 33 per cent), which means that variations are thus more readily detected.

The procedure followed in the low-selection series $A$ is typical of all the series and can be taken as a sample. A single white miniature female mated to a red long male gave $\mathrm{F}_{1}$ white miniature males, $\underline{w} \quad \mathrm{~m}$, and long red females $\frac{W}{W}-\frac{m}{M}$, the latter being double heterozygotes. The $F_{1}$ sibs were mated in pairs in 8-drachm homeopathic vials, and the pairs were removed to new vials about every three days. The culture methods were those commonly used with Drosophila. The $\mathrm{F}_{2}$ offspring from each vial were classified daily until a fair sample of each $F_{1}$ female's 'crossover capacity' was obtained. As expected, the offspring were of four kinds: the parental types, red long, and white minature and the crossovers red miniature and white long. It was impossible to anticipate which $\mathrm{F}_{1}$ female was going to be selected because of her low crossover ratio determined by a reasonably large progeny, and it was likewise virtually impossible to continue mating in pairs the sibs from each $F_{1}$ female until we could find out which line was going to be used to continue the selection. Thus in $\mathrm{F}_{1}$ series $\mathrm{A}$, low selection (table 1), there were twenty-eight pairs of $\mathbf{F}_{1}$ individuals, several of which appeared to be promising material, but we eventually chose pair 15 , which gave $21: 98=21.43$ per cent. ${ }^{3}$ By the time we

${ }^{3}$ In giving crossover values we shall put the data in the following order throughout this paper: crossovers: total-per cent of crossing over. The classes are always the same and repetition can thus be avoided. 
were in position to know that pair 15 would be selected, practically all of its $\mathrm{F}_{2}$ offspring had emerged. Therefore it seemed expedient to mate en masse the $\mathrm{F}_{2}$ offspring (i.e., red long females $\frac{\mathrm{w}}{\mathrm{W}} \frac{\mathrm{m}}{\mathrm{M}}$, miniature white males $\underline{\mathrm{w}} \mathrm{m}$ ) from each of several promising pairs, to perpetuate the promising lines. Hence, in table 1 , the $F_{2}$ sibs came from the selected $F_{1}$ pair, no. 15, and were mated en masse, giving 25.46 per cent crossovers. The $\mathrm{F}_{3}$ offspring were then mated in pairs, and selection was again exercised. This means that an odd-numbered generation $\left(\mathbf{F}_{1}\right.$, $\mathrm{F}_{3}$, etc.) in table 1 , for example, represents the mating of pairs, while an even-numbered generation represents the mating en masse of sibs from the selected pair. It will be clear that inbreeding was very intense throughout all series, for the pair gave sibs, and the sibs from the selected pair mated en masse gave a population in which the most remote relationship could be double cousins, but it might be as close as sibs again. Thus we had alternate generations of double cousins (or nearer relatives) mated in pairs of which we selected the offspring (a sibship) of the most promising pair to mate en masse. Selection therefore really took place in alternate generations. While we recognized that this procedure was not ideal theoretically, at least from the point of view of a strict selection experiment, the advantages outweighed the disadvantages, inasmuch as it made the whole selection experiment possible in a practical sense and yet maintained inbreeding. The chief disadvantage lies in the fact that this method precludes calculation of the parent-offspring correlation and regression coefficient for any two successive generations.

In all these selection experiments, after the $\mathrm{P}_{1}$ generation, all of the matings were of the type $\frac{\mathrm{w}}{\mathrm{W}}-\frac{\mathrm{m}}{\mathrm{M}} \times \underline{\mathrm{w}} \quad \mathrm{m}$; i.e., red long females heterozygous in white miniature mated to white miniature males, except where special tests were made for the sake of genetic analysis. This type of mating gave crossovers among the offspring of both sexes and thus a more effective criterion for selection, since numbers were doubled. It also gave the doubly heterozygous females and the ultimate recessive 
males as two of the four most frequent classes, which was very convenient, since these were used again for mating in the next generation. Writing the form of all matings for every generation in tables 1 to 6 in the usual Mendelian terms we have:

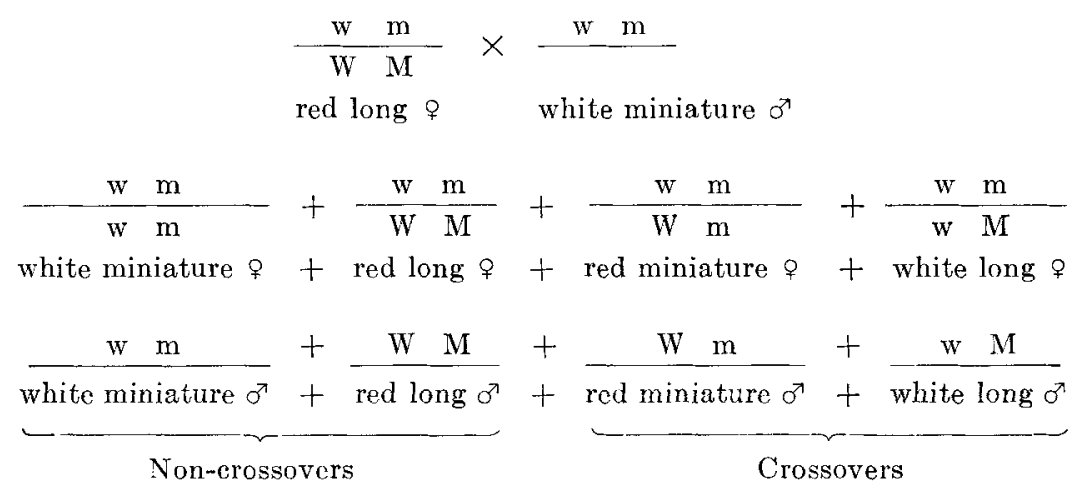

THE DATA

Series $A$; low selection

Table 1 and text figure 1 give the main facts of this selection experiment. The $\mathrm{F}_{1}$ generation consisted of twenty-eight pairs whose total progeny showed 27.11 per cent crossovers. This is a little lower than might be expected in a general population, but the difference between this ratio and Sturtevant's (given in Morgan and Bridges, '16) ratio of 32.8, based on 41,034 progeny, is no greater than that recorded by Bridges (Morgan and Bridges, '16), who gives data showing 38.3 per cent crossover. This same stock has repeatedly given crossover ratios close to 33 per cent.

The crossover values in this and other similar tables are treated as variables and classified in frequency distributions in which the class interval is 3 per cent. The average of each class is placed at the head of the columns, e.g., 1.5, 4.5, 7.5, etc., which means that the class ranges were $0-3,3-6,6-9$, and so forth. The crossover values in the $\mathrm{F}_{1}$ ranged from 10 per cent to 36.8 per cent. There is no doubt but that some of these ratios have little meaning, for they are based upon small totals. We have 
TABI.E 1

Series $A$ : low selection

\begin{tabular}{|c|c|c|c|c|c|c|c|c|c|c|c|c|c|c|c|c|c|c|c|c|}
\hline \multirow{2}{*}{ 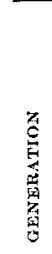 } & \multirow{2}{*}{ 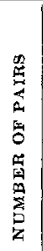 } & \multicolumn{14}{|c|}{$\begin{array}{l}\text { THE DISTRIBUTION OF CROSSOVER VALUTS } \\
\text { IN GACH GENERATION }\end{array}$} & \multirow{2}{*}{ 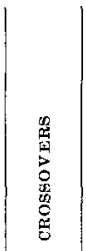 } & \multirow{2}{*}{ 总 } & \multirow{2}{*}{ 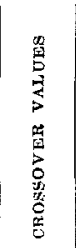 } & \multirow{2}{*}{ 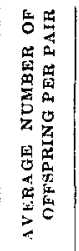 } & \multirow{2}{*}{$\begin{array}{l}\text { THE SELECTED } \\
\text { PAIR GAVE }\end{array}$} \\
\hline & & $\rightarrow 2$ & 20 & 2 & $\dddot{\ddots}$ & \begin{tabular}{|l|l}
$\infty$ \\
$\infty$ \\
$\infty$
\end{tabular} & ڤ. & 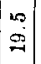 & สุ & 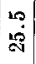 & 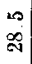 & $\stackrel{\infty}{\infty}$ & की & $\begin{array}{l}10 \\
1 \\
-50\end{array}$ & 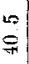 & & & & & \\
\hline $\begin{array}{l}\mathrm{F}_{1} \\
\mathrm{~F}_{2}\end{array}$ & 28 & & & & 1 & 1 & 2 & 1 & 6 & $\begin{array}{r}3 \\
\times \\
\end{array}$ & 4 & 4 & 5 & 1 & & $\begin{array}{r}427 \\
97\end{array}$ & $\begin{array}{r}1,575 \\
381\end{array}$ & $\begin{array}{l}27.11 \\
25.46\end{array}$ & 56.3 & $21: 98$ \\
\hline $\begin{array}{l}F_{3} \\
F_{4}\end{array}$ & 27 & & & & & 1 & 1 & & 5 & $\begin{array}{r}8 \\
\times\end{array}$ & 4 & 5 & 1 & 2 & & $\begin{array}{r}1,037 \\
206\end{array}$ & $\begin{array}{r}3,760 \\
787\end{array}$ & $\begin{array}{l}27.58 \\
26.18\end{array}$ & 139.3 & $34: 189=17.99$ \\
\hline $\begin{array}{l}F_{5} \\
F_{6}\end{array}$ & 56 & 1 & & 1 & & 3 & 7 & & $\begin{array}{r}5 \\
\times\end{array}$ & 9 & 11 & 4 & 2 & 2 & 2 & $\begin{array}{r}2,188 \\
197\end{array} \mid$ & $\begin{array}{r}8,660 \\
920\end{array}$ & $\begin{array}{l}25.27 \\
21.41\end{array} \mid$ & 154.6 & $44: 210=20.95$ \\
\hline $\begin{array}{l}\mathrm{F}_{7} \\
\mathrm{~F}_{8}\end{array}$ & 45 & 10 & & 1 & & 1 & 6 & $\begin{array}{r}7 \\
\times\end{array}$ & 5 & 7 & 4 & 2 & 2 & & & $\begin{array}{l}905 \\
125\end{array}$ & $\begin{array}{r}4,234 \\
612\end{array}$ & $\begin{array}{l}21.37 \\
20.42\end{array}$ & 94.1 & $9: 104=8.65$ \\
\hline $\begin{array}{l}F_{9} \\
F_{10}\end{array}$ & 43 & $\left|\begin{array}{c}14 \\
\times\end{array}\right|$ & 1 & 2 & & 3 & 5 & 4 & 7 & 3 & 4 & & & & & $\begin{array}{r}478 \\
0\end{array}$ & $\begin{array}{r}2,899 \\
53\end{array}$ & $\begin{array}{r}16.49 \\
0.00\end{array}$ & 67.4 & $0: 131=0.00$ \\
\hline $\mathbf{F}_{11}$ & 5 & 5 & & & & & & & & & & & & & & 0 & 87 & 0.00 & 17.4 & $0: 12=0.00$ \\
\hline $\mathrm{F}_{12}$ & & $x$ & & & & & & & & & & & & & & 2 & 148 & 1.35 & & \\
\hline
\end{tabular}

Per cent of crossovers

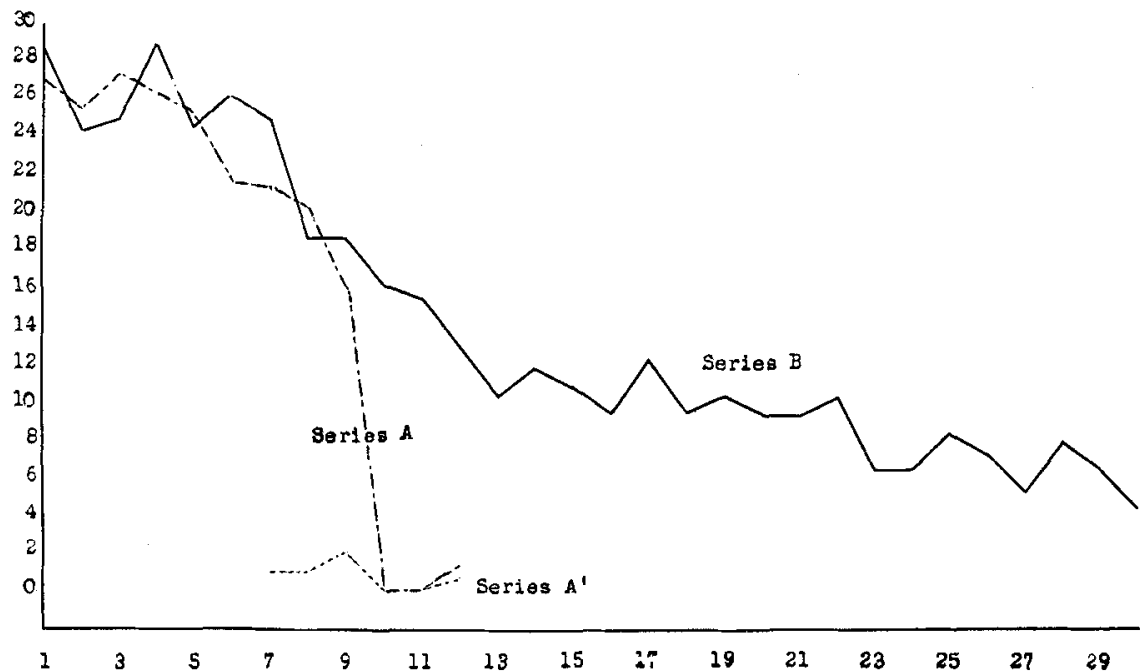

Generations

Fig. 1 Series A, A', and B, low selection 
recourse to at least two methods of dealing with such unproductive pairs. We can either include in our frequency distribution only those females on which we have ample data to give a somewhat reliable crossover value and ignore all pairs giving less offspring than a fixed minimum (fifty individuals for, example), or we can simply include all females and thus withhold no data. The latter course seemed preferable and we have followed it. There were five pairs showing lower crossover values than the one we selected, as follows: $10.0 ; 12.5 ; 16.0$; $16.6 ; 20.7$. We did not always select the lowest absolute value, for in many cases this was based upon an insufficient number of offspring. It was also necessary to keep fertility in mind, in order to insure the perpetuation of our selected line. This explanation will make clear why we could not always choose the lowest absolute crossover value in the frequency distribution of any given generation. In table 1 the italicized frequency in each distribution shows the relative position and value of the selected pair. No dispersion can be given for the $F_{2}, F_{4}, F_{6}$, etc., since these represent en-masse matings. An $\mathrm{x}$ represents the point to which the progeny of the pair selected in the preceding generation regressed. The average number of offspring per pair shows how reliable the crossover values usually were in this experiment. The crossovers, total, and the crossover value for each selected pair are also given in the last column. Those generations which have any number of pairs entered under that heading are generations in which all matings consisted of pairs, while the other alternating generations were en-masse matings. Since the crossover value of a female may be based upon a small number of offspring in some cases, and thus give an apparently wide deviation which has little significance, we have not calculated the variability of each generation in this paper. For example, a female showing a crossover value of 10 per cent based upon twenty offspring might well show 30 per cent if one hundied and fifty offspring had been secured, since age and changing temperature affect crossing over; or she might even show 10 per cent based upon twenty offspring as a sheer fluctuation of sampling. 
The first two selections seemed to show little or no effect. Although the values of the selected pairs were low, their progeny regressed practically to the parental average. Possiblythis means that all wide deviations were not necessarily due to genetic causes and that we had diffculty in distinguishing between wide environmental variates and wide variations due to genetic causes. Selection was thus effective only when by chance we chose a wide variate due to the latter set of causes. For example, in the $\mathrm{F}_{3}$, we chose a female showing 17.99 per cent crossovers, but her progeny gave an average of 26.18 per cent. After the $F_{5}$, progress was very rapid. The $F_{9}$ gave 16.49 per cent, and the $F_{10}$ to $F_{13}$ gave about 0 per cent. These last generations in this series were based upon small totals, because the excessive heat $\left(90^{\circ}\right.$ to $100^{\circ} \mathrm{F}$, day and night) for long-continued periods reduced fertility to a minimum and eventually annihilated our stock in this one. However, series $A^{\prime}$, which was derived directly from series $A$, gave just as low crossover values with larger numbers and under better conditions. We may be quite sure that temperature was not the cause of low crossing over; for, if we may anticipate, series B showed effects of selection under normal temperature conditions.

Series $A^{\prime}$, low selection; derived from series $A$

In the $\mathrm{F}_{7}$ generation of series $A$, two selections were made. One female ( $q$ 14) gave 9:104 $=8.65$ per cent, and a second female (o 10) gave 1:91 $=1.10$ per cent. The former was used to continue series $A$, while the latter was used to begin a new series, $A^{\prime}$. Table 2 and text-figure 1 give the main facts pertaining to series, $A^{\prime}$. We began this series to insure keeping alive some of the low crossover material of series A during continuously hot weather. Our facilities did not permit controlling temperature, and the whole experiment was in a precarious situation during the early summer months of 1916 . We found that mating a number of females en-masse assured more progeny than the same number of females mated in individual bottlesevidently because the larger number of larvae carried the yeast through the culture and kept molds down. Hence, during the 
summer months of 1916 , we made numerous en-masse matings in this series to insure keeping the stock alive. Beginning with a single $F_{7}$ pair of series $A$ showing 1:91 $=1.10$ per cent, the new series $A^{\prime}$ was run for nine generations. All generations were en-masse matings except $F_{9}$ and $F_{14}$, in which paired matings were made to ascertain what the crossover values of the individual females might be in this line. In the $\mathrm{F}_{9}$ the average crossover value for the total population was 8:397 $=2.02$ per cent. The wide dispersion in this generation does not carry

TABLE 2

Series $A^{\prime}$ : derived from series $A$

\begin{tabular}{|c|c|c|c|c|c|c|c|c|c|c|c|}
\hline \multirow{2}{*}{$\begin{array}{l}\text { GENERA- } \\
\text { TION }\end{array}$} & \multirow{2}{*}{$\begin{array}{l}\text { NUMBer } \\
\text { OF PAIRS }\end{array}$} & \multicolumn{7}{|c|}{$\begin{array}{l}\text { THE DISTRIBUTION OF CROSSOVER } \\
\text { VALUES IN FACH GENHRATION }\end{array}$} & \multirow{2}{*}{ Chossovers } & \multirow{2}{*}{ TOTALS } & \multirow{2}{*}{$\begin{array}{l}\text { CROSSOVER } \\
\text { VALUES }\end{array}$} \\
\hline & & 1.5 & 4.5 & 7.5 & 16.5 & 13.5 & 16.5 & 19.5 & & & \\
\hline $\mathrm{F}_{7}$ & \multirow{6}{*}{18} & 1 & \multirow{9}{*}{2} & & \multirow{9}{*}{1} & & & \multirow{9}{*}{1} & 1 & 91 & 1.10 \\
\hline $\mathrm{F}_{8}$ & & $x$ & & & & & & & 1 & 86 & 1.16 \\
\hline $\mathrm{F}_{9}$ & & 14 & & & & & & & 8 & 397 & 2.02 \\
\hline$F_{10}$ & & $x$ & & & & & & & 0 & 61 & 000 \\
\hline$F_{11}$ & & $x$ & & & & & & & 0 & 133 & 000 \\
\hline $\mathrm{F}_{12}$ & & $x$ & & & & & & & 4 & 373 & 1.07 \\
\hline$F_{13}$ & \multirow{3}{*}{$25^{1}$} & $x$ & & & & & & & 9 & 1,473 & 0.61 \\
\hline$F_{14}$ & & 25 & & & & & & & 10 & 2,253 & 0.44 \\
\hline$F_{1 s}$ & & $x$ & & & & & & & 0 & 289 & 0.00 \\
\hline \multicolumn{9}{|l|}{ Total. } & 33 & 5,156 & 0.64 \\
\hline
\end{tabular}

1 See text.

much weight because cultural conditions were poor and fertility was low. Pair no. 4, for example, gave $3: 15=20$ per cent, but such a pair might well give a much lower crossover value with a larger number of offspring. The $\mathrm{F}_{14}$ gave 10:2253 $=0.44$ per cent, and the numbers are large enough to be significant. This generation included twenty-five pairs which gave a total of $2: 977=0.20$ per cent, and an en-masse mating which gave 8:1276 $=0.63$ per cent. There can be no doubt but that an original crossover value of 33 per cent has been changed by selection, at least, that a marked change has followed selection. For nine generations the stock bred true to about 0 per cent crossover. The totals for series $A^{\prime}$ were $33: 5156=0.64$ per cent. 
Series $A^{\prime}$, like series $A$, was eventually lost in the latter part of the summer of 1916 becautse of an unavoidable succession of events. We regretted the loss of this stock because we had hoped to make a genetic analysis of the last generations in an attempt to learn what was taking place during selection. However, the data as they stand indicate that crossing over is not a very stable phenomenon and that it can be rather easily modified. We surely cannot concur in Morgan's ('19) view that crossing over "gives numerical results of extraordinary constancy."

We immediately began a new selection experiment, hoping that we could duplicate the results of series $A$ and $A^{\prime}$.

\section{Series B; low selection}

Series $B$, like the preceding series $A$ and $A^{\prime}$, began with the mating of a single white miniature female and a wild red long male. In fact; as a prelude to series $B$, we made eighty such paired matings, for we had found some non-disjunction in our original stocks and in series $A$ and $A$ '. Since non-disjunction theoretically lowers the percentage of crossing over (Bridges, '16), we wished to assure ourselves, if possible, that this cause might not be operative in producing low crossover values in our selection experiment. Of the eighty white miniature females tested we found eleven giving either matriclinous daughters or patriclinous sons or both. This must mean secondary non-disjunetion in the white miniature stock, for the exceptions were too numerous to be considered primary. We chose white miniature 53 mated to a wild male as the foundation pair for our experiment, because this pair gave fifty-two wild-type daughters and seventy-eight miniature white sons. While they showed no exceptions, it does not prove that +53 may not have been nondisjunctional $(\mathrm{XXY})$, for a ratio of $0:(52+78)$ might well occur as a chance ratio where an average of 4.3 per cent of exceptions is expected from XXY females (Bridges, '16). However, in the present paper we are concerned only with the question whether selection based on variable crossover ratios can be effec- 
tive. Whether non-disjunction has any necessary relationship to our result will be discussed in a subsequent paper.

TABLE 3

Series B: low selection

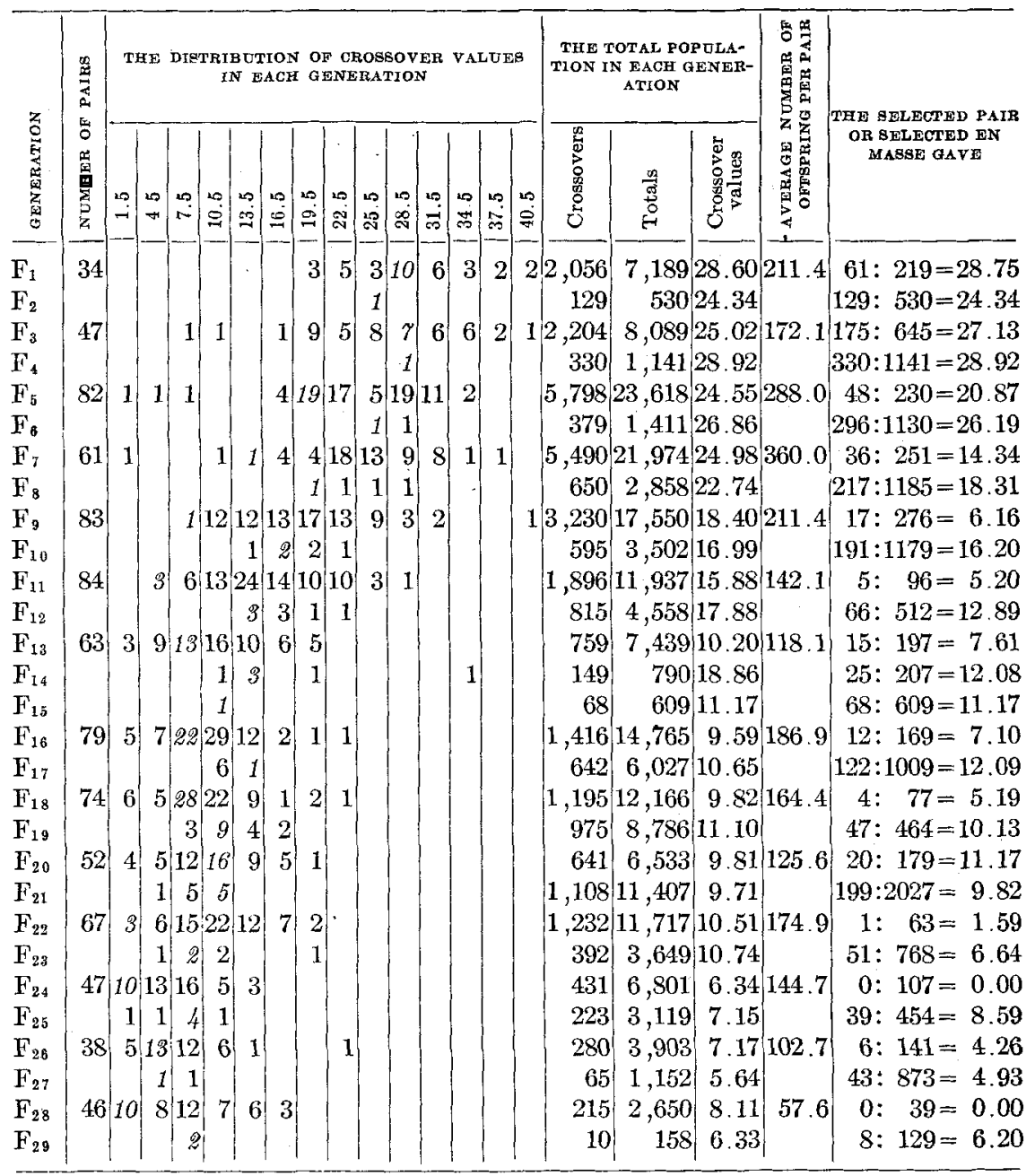

The $F_{1}$ sibs from $\% 53$ were mated in thirty-four pairs and gave as a whole a crossover value of 28.60 per cent (table 3 ). 
In order to further test our foundation stock, the $F_{1}$ offspring of \% 25 (one of the eighty $P_{1} q q$, and similar to $q 53$ ) were tested en-masse and gave $1142: 3553=32.14$ per cent. The $\mathrm{F}_{1}$ offspring of several other $\mathrm{F}_{1} \&$ क were mated en-masse and gave $830: 2923=28.40$ per cent. All of these facts indicate that our foundation stock was quite normal with respect to crossing over and gave crossover values of the same general magnitude as those ordinarily used in plotting maps of the sex. chromosome.

The main facts pertaining to series $\mathrm{B}$ are given in text figures 1 and 2 and in tables 3 and 4 . Table 3 was constructed in the

Per cent of crossovers

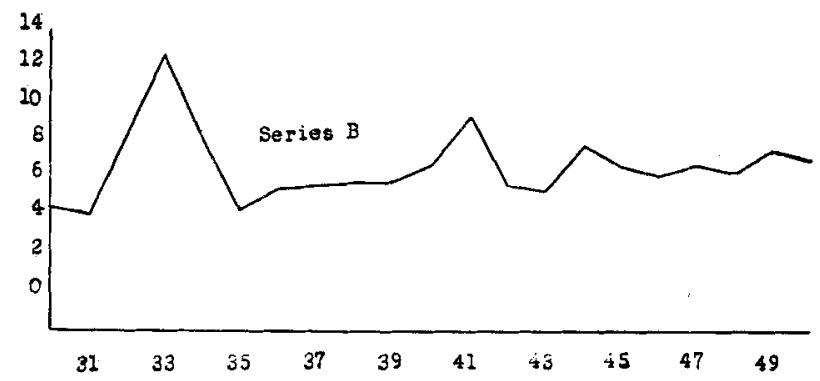

Generations

Fig. 2 Series B, continued, low selection

same way as table 1 , with the following exception: in series $B$, records of the en-masse matings of the offspring from several promising pairs were kept and the crossover values of all these are put in the form of a frequency distribution, but the italicized frequency shows the position of the en-masse mating which was derived from the pair eventually selected to continue the experiment. The italicized frequency in the distribution of the pairs likewise shows what the value of the chosen pair was. The first three columns at the right of table 3 give the data for the total population in each generation. The average number of offspring per pair shows that the fertility was high and selection was based upon what seemed to be adequate numbers. The last column gives the number of crossovers total, and crossover value 
of the selected pair in each generation and the same data for en-masse matings from these selected pairs. Text figures 1 and 2 give a graphic representation of the progress made in series $B$. The graphs are based upon the crossover values in the selected line; i.e., all en-masse matings except the selected one have been neglected in plotting the graph. In other words, the graph relates only to the actual line of selection, and all side lines have no weight in determining the coordinates. It will be clear that those generations in table 3 which have any number of pairs entered under that heading were generations made up entirely of paired matings, while all other generations were en-masse matings.

The first three selections had little or no effect, but it cannot be said that selection was very rigid during these generations. In $F_{7}$ we selected a pair giving $36: 251=14.34$ per cent and made some progress, for the next seven generations $\left(\mathbf{F}_{8}-F_{14}\right)$ fluctuated between 10 per cent and 23 per cent. The subsequent nine generations $\left(\mathrm{F}_{15}-\mathrm{F}_{\dot{2}_{3}}\right)$ fluctuated around 10 per cent. Selection was carried on up to $\mathrm{F}_{29}$ and the last six generations $\left(\mathrm{F}_{24}-\mathrm{F}_{29}\right)$ varied around $\cdot 6$ per cent. ${ }^{4}$ After that we simply carried the stock without selection, and have found it to breed quite true to low crossover for twenty-two generations. The $\mathrm{F}_{29}-\mathrm{F}_{50}$ have given values around 6 per cent. These last twentyone generations are shown in table 4 .

There are some features of tables 3 and 4 which require comment for the sake' of clearness. . Temperature conditions made it necessary to breed the offspring of the selected pair in the $F_{13}$ for two generations by the ${ }^{*}$ use of en-masse matings. Hence, the matings in the $F_{14}$ and $F_{15}$ show no pairs and selection was interrupted. This was the only case in which the usual sequence of selecting in alternate generations was not followed. The $\mathrm{F}_{33}$ showed a rather abrupt rise in crossover value (12.50 per cent),

\footnotetext{
${ }^{4}$ An independent mutation of gray to yellow which occurred in the $\mathrm{F}_{25}$ should perhaps be put on record. One female ( 9 no. 30) proved to be heterozygous for yellow, and this gene was linked to white and miniature. Hence the mutating gene came through the spermatozoon from the gray white miniature father of $\$ 30$. This new gene for yellow proved to be identical with the original yellow mutation found by Wallace in 1911 (Morgan and Bridges, '16).
} 
which was without doubt due to high temperature, as our records indicate. The fertility was low and we obtained with much effort from en-masse matings in the $F_{32}$ and $F_{33}$ only forty-eight and eighty individuals, respectively, while under ordinary conditions several thousand would have been possible. As soon as normal conditions were restored, the usual low crossover values were again found. The $F_{41}$ showed a rather unexpected rise

TABLE 4

Series B-Continued

\begin{tabular}{c|r|r|c}
\hline GENERATION & CROs8OV ERs & TOTALs & CROSSOVER VALUES \\
\hline$F_{30}$ & 6 & 144 & 4.17 \\
$F_{31}$ & 7 & 171 & 4.09 \\
$F_{32}$ & 4 & 48 & 8.33 \\
$F_{3 z}$ & 10 & 80 & 12.50 \\
$F_{34}$ & 52 & 643 & 8.09 \\
$F_{35}$ & 48 & 1,147 & 4.18 \\
$F_{36}$ & 55 & 1,032 & 5.33 \\
$F_{37}$ & 46 & 814 & 5.65 \\
$F_{38}$ & 39 & 697 & 5.60 \\
$F_{38}$ & 55 & 954 & 5.77 \\
$F_{40}$ & 72 & 1,074 & 6.70 \\
$F_{41}$ & 94 & 1,015 & 926 \\
$F_{42}$ & 463 & 8,564 & 5.41 \\
$F_{48}$ & 47 & 901 & 5.22 \\
$F_{44}$ & 103 & 1,312 & 785 \\
$F_{45}$ & 43 & 661 & 6.51 \\
$F_{48}$ & 59 & 992 & 5.95 \\
$F_{47}$ & 69 & 1,021 & 6.76 \\
$F_{48}$ & 45 & 734 & 6.13 \\
$F_{48}$ & 81 & 1,081 & 7.49 \\
$F_{50}$ & 96 & 1,375 & 6.98 \\
\hline
\end{tabular}

(9.26 per cent), but since there were no unusual temperature conditions, we must regard this somewhat higher value as without peculiar significance. The subsequent generations dropped to about 6 per cent again. 


\section{Series $C$; high selection}

In the $F_{1}$ generation of series $A$, pair number 21, was chosen to begin a high-selection series, series $C$. While this series was carried for only eight generations, and then discarded in order to devote time to the other series, nevertheless brief mention should be made because the results may aid us in interpreting series $A, A^{\prime}$, and $B$. We were not able to make progress in selecting upward, as the averages of table 5 show. (Table 5 was constructed in the same way as tables 1, 2, and 3.) On the contrary, we were much surprised to find that in the $F_{7}$ generation a number of pairs suddenly dropped to very low

TABLE 5

Series $C:$ high selection

\begin{tabular}{|c|c|c|c|c|}
\hline GENERATION & NUMBER OF PAIRS & CROSSOVERS & TOTALS & CROSSOVER VAL DES \\
\hline$F_{1}$ & 28 & - 427 & 1,575 & 27.11 \\
\hline $\mathrm{F}_{2}$ & & 162 & 512 & $31: 64$ \\
\hline$F_{3}$ & 35 & 1,407 & 4,842 & 29.06 \\
\hline $\mathrm{F}_{4}$ & & 436 & 1,355 & 32.18 \\
\hline $\mathrm{F}_{6}$ & 90 & 6,465 & 21,071 & 30.68 \\
\hline$F_{6}$ & & 684 & 2,267 & 30.17 \\
\hline $\mathrm{F}_{7}$ & 72 & 3,893 & 13,705 & 28.41 \\
\hline $\mathrm{F}_{8}$ & & 296 & 1,298 & 22.80 \\
\hline
\end{tabular}

crossover values; in fact, much lower ratios than one would find in any ordinary population such as our original stocks or our $\mathrm{F}_{1}$ of table 1 . The distribution of the $\mathrm{F}_{7}$ in series $\mathrm{C}$ is given in table 6 . It will be noted that nine pairs gave values lower than 6 per cent. Their values were as follows:

$$
\begin{aligned}
& 4: 72=5.56 \\
& 5: 279=1.79 \\
& 9: 164=5.49 \\
& 1: 142=0.70 \\
& 1: 82=1.22 \\
& 0: 123=0.00 \\
& 4: 104=3.85 \\
& 2: 40=5.00 \\
& 0: 49=0.00
\end{aligned}
$$


There can be no doubt that these crossover values are significantly different from any ratio in the $F_{1}$ in table 1 , or from the usual ratios shown by random stock females. Furthermore, there is an interval of about 10 per cent between the lower and higher groups of table 6 , in which we found no crossover values. The natural inference is that any attempt to increase the amount of crossing over leads to double crossing over, and thus to very low crossover values (practically zero). That is, these nine females showed a marked decrease in crossover values, despite high selection, because they gave almost nothing but double crossovers. In other words, their low crossover values are, after all, the result of effective high selection. Mr. L. E. Thorne, who had this series under observation, was called into military service and we did not make any further tests on this material.

TABLE 6

The distribution of crossover values in the $F_{7}$ generation of series $C$

\begin{tabular}{|c|c|c|c|c|c|c|c|c|c|c|c|c|c|c|}
\hline \multirow{2}{*}{$\begin{array}{l}\text { NUMBER } \\
\text { OF PAIRS }\end{array}$} & \multicolumn{11}{|c|}{ THE DISTRIBUTION OF CROSSOVER VALUEB } & \multirow[b]{2}{*}{ CrOSSOVERS } & \multirow{2}{*}{ TOTAL } & \multirow{2}{*}{$\begin{array}{c}\text { GROSSOVBR } \\
\text { VALUE }\end{array}$} \\
\hline & -10 & : & $\left|\begin{array}{l}0 \\
0 \\
0\end{array}\right|$ & $\mid \begin{array}{l}2 \\
0\end{array}$ & \begin{tabular}{l|l} 
& 0 \\
9 & 0
\end{tabular} & 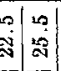 & $\mid$\begin{tabular}{l|l}
20 \\
0 \\
$\therefore$
\end{tabular} & \begin{tabular}{l|l|}
8 \\
$\dot{0}$ \\
0
\end{tabular} & $\mid$\begin{tabular}{l|}
20 \\
50 \\
00
\end{tabular} & \begin{tabular}{|l|}
5 \\
0
\end{tabular} & a & & & \\
\hline 72 & 5. & & & 1 & 16 & $6|8|$ & 1516 & 6 & 6 & 1 & 1 & 3,893 & 13,705 & 28.41 \\
\hline
\end{tabular}

We hope, however, to repeat the high-selection experiment and test out the region between white and miniature in such females which apparently give uniform double crossing over in a region in which single crossing over is the rule.

\section{DISCUSSION AND SUMMARY}

As far as we are aware, there is only one record of a similar selection experiment. Gowen ('19) selected for high and low crossover values, but his results and conclusions are diametrically opposed to ours, since, he found selection ineffective, and concluded there were no differences in modifying factors for crossing over in his experiment. He continued selection for only five generations in the low series and six in the high, using the region of the third chromosome between sepia and rough. 
While it is possible that this chromosomal region may fail to show the same phenomenon which we found in the sex chromosome, we are rather inclined to believe that the difference between our results and Gowen's is more likely due to differences in the method of procedure, for Gowen states that his "chief difficulty lies in the few individuals that it was possible to include in a given generation." Gowen gives only the mean total crossing over in each generation, and we do not know how rigid his selection may have been, for he does not state how many pairs were included in each generation nor does he give the frequency distribution for crossover values. We suspect that he found the same impediments in using strict brother-and-sister matings which we found and which prompted us to use en-masse matings in alternate generations to increase our numbers. We are carrying on selection experiments in other regions of the sex chromosome and in the autosomes, which should decide whether other regions and chromosomes are similarly affected by selection. We have no reason to suppose that they will not be.

The effects of selection upon crossover values may be due to one or a number of causes, some of which suggest themselves almost immediately. It would hardly be profitable to expatiate on these, since we are making tests, which we hope may indicate what has really happened in the course of selection. Briefly stated, we think of the following possible causes which may have been operative in modifying our crossover values:

1. We may perhaps have dropped out a large part of the chromosome between white and miniature, thus bringing these two genes closer together. We can probably disregard this as a cause, for although 'deficiency' reduces crossing over (Bridges, '17) nevertheless the lethal action of deficiency would be seen in a disturbed sex ratio. We found no such disturbance.

2. Is it possible that we may have moved the locus of the genes on the chromosome? This would mean that the locus of a gene is not permanently fixed, but that a given gene is found in a characteristic position in the majority of cases. If we have done this, and at the same time have not moved other genes, then linkage tests should disclose this fact, for the order of the genes would be changed. 
3. In series $\mathrm{A}$ and $\mathrm{A}^{\prime}$ we found much evidence of non-disjunction. Bridges ('16) stated that XXY females should logically show a decrease in crossing over, because heterosynapsis takes place in about 16.5 per cent of the cases and precludes crossing over in these cases. However, Bridges also showed that the experimental results disagree with such an expectation, for crossing over was not decreased among the regular sons of XXY females, but as far as the evidence goes it was slightly increased. For some time we labored under the impression that much, if not all, of our decreased crossing over was associated with the presence of non-disjunction (Detlefsen and Roberts, '20). We are now rather inclined to believe we were in error. It should not be a difficult matter to free our low crossover stock in series $\mathrm{B}$ from non-disjunction and thus dissociate this possible cause from the others: We could in this way demonstrate that nondisjunction was only accidentally present in our experimental material and that our results are quite independent of non-disjunction.

4. Have we reduced the frequency of the usual single 'chromosome twist' between white and miniature to a minimum? Weinstein's ('18) results indicate that crossing over takes place in the sex chromosome with about forty-six units as the modal distance between successive crossovers. Similarly, Gowen ('19) found twenty-five to thirty units in the case of the third chromosome. We began with two genes which were about thirty-three units apart, and which should therefore show a single crossover as the characteristic or modal number. This would mean that in series $A, A^{\prime}$, and $B$ we have practically eliminated the usual single crossover in this region, while in series $\mathrm{C}$ we were on the way to increasing it to two crossovers (i.e., a double crossover), which would give us no crossing over as far as these two genes were concerned. Does this mean that we can decrease or increase the amount of 'twisting' which members of an homologous pair of chromosomes may show, and which is supposed to be responsible for crossing over according to the chiasmatype theory? If selection can accomplish this, then we may reasonably suppose that numerous hereditary modifying factors are 
present in a general population and are the basis and cause of this variable chiasmatype relationship. If this explanation is correct (and we are inclined to believe it the most plausible one of those we have suggested here), then we cannot escape a marked change in our view-point on crossing over and related phenomena. If, for example, all of the difference between practically no crossing over in our series $\mathrm{A}$ and $\mathrm{A}^{\prime}$ and normal crossing over ( 33 per cent) is due to numerous modifying factors, then we naturally begin to wonder just what part 'distance between two genes' on a chromosome may play in determining linkage values. Our current view is that "the percentage of cases in which two linked genes separate (amount of crossing over between them) is necessarily proportional, other things being equal, to the distance between the genes," (quoted directly from Weinstein ('18)). But evidently the percentage of crossing over is a variable which is the expression of different possible combinations of multiple modifying factors; hence the percentage of crossing over cannot be proportional to the distance if the distance remains uniform. For example, in series $B$ we find 6 per cent crossing over, and so we should conclude that the distance in this stock is $2 / 11$ or 18 per cent of what it was when we began selection! Thus, to maintain our original position, we must conclude that the percentage of crossing over and distance are correlated variables, if the proportion between the two is to remain reasonably constant. We then naturally begin to wonder what has happened to all of the distance (and the genes) between 0 and 33 in series $A$ and $A^{\prime}$ where crossing over has been practically eliminated. In view of these considerations, it would perhaps be simpler to conclude that the percentage of crossing over is not necessarily proportional to the distance. The distance may remain fairly constant, but the amount of erossing over (i.e., twisting of the chromosomes) will depend upon numerous hereditary factors.

One recalls in this connection Goldschmidt's ('17) suggestive paper in which he postulated variable forces that hold genes to their customary loci on the chromosome and which allow an exchange between allelomorphs in a certain average percentage 
of cases. While we cannot subscribe fully to this theory for cogent reasons advanced by Sturtevant ('17), Bridges ('17), and Jennings ('18), nevertheless Goldschmidt's proposèd theory would tot appear entirely supererogatory, for a crossover value is apparently a variable and the variation is due to or controlled by multiple hereditary factors. A cross between low crossover stocks and the original population, and testing out a large number of $F_{2}$ segregates should throw the desired light on this question. Unpublished data indicate that segregation in crossover values does take place as one would expect on the basis of the multiple-factor explanation.

5. May we suppose that we have been taking advantage of small mutations in the nature of modifying factors arising during the course of selection? While this is possible we are inclined to doubt it, for favorable mutations evidently do not take place in the direction of selection as readily as this view would imply (cf. Muller and Altenburg, '19).

The following conclusions may be drawn from the data of this paper:

1. Crossover values are very variable and part of this variability is due to genetic causes.

2. Low selection has been effective in two entirely independent series, $\mathrm{A}$ and $\mathrm{B}$.

3. The low crossover stock bred true to about 0.6 per cent (almost zero) for nine generations in series $A^{\prime}$ (derived from series A).

4. The low crossover stock bred true to about 6 per cent for twenty-two generations in series B.

5. High selection probably induces double crossing over, as shown by series $\mathrm{C}$.

6. Crossing over in the various regions of the sex chromosome (and other chromosomes?) is probably controlled by multiple incompletely dominant factors. 


\section{LITERATURE CITED}

Bridges, C. B. 1915 A linkage variation in Drosophila. Jour. Fxp. Zoöl., vol. 19 , pp. 1-21.

1916 Non-disjunction as proof of the chromosome theory of heredity. Genetics, vol. 1, pp. 1-52, 107-163.

1917 An intrinsic difficulty for the variable force hypothesis of crossing over. Am. Nat., vol. 51, pp. 370-373.

1917 Deficiency. Genetics, vol. 2, pp. 445-465.

Detlefsen, J. A. ANd Roberts, E. 1920 Variation in the percentage of crossovers and selection in Drosophila melanogaster. Anat. Rec., vol. 17, p. 336.

Goldschmidt, R. 1917 Crossing over ohne Chiasmatypie? Genetics, vol. 2, pp. 82-95.

Gowen, J. W. 1919 A biometrical study of crossing over. On the mechanism of crossing over in the third chromosome of Drosophila melanogaster. Genetics, vol. 4, pp. 205-250.

Jennings, H. S. 1918 Disproof of a certain type of theories of erossing over between chromosomes. Am. Nat., vol. 52, pp. 247-261.

Morgan, T. H., AND Bridges, C. B. 1916 Sex-linked inheritance in Drosophila. Publ. Carnegie Inst. Wash. D. C., no. 237, pp. 1-87, 8 fig., 2 pl.

Morgan, T. H. 1919 The physical basis of heredity. J. B. Lippincott Co., Philadelphia and London. 305 pp., 117 fig.

Muller, H. J., and Altenburg, E. 1919 The rate of change of hereditary factors in Drosophila. Proc. Soc. Exp. Biol. and Med., vol. 17, pp. 10-14.

Plough, H. H. 1917 The effect of temperature on crossing over in Drosophila. Journ. Exp. Zool., vol. 24, pp. 147-210.

Stdrtevant, A. H. 1917 Crossing over without chiasmatype. Genetics, vol. 3, pp. 301-304.

1919 Inherited linkage variations in the second chromosome. Pub. Carnegie Inst. Wash. D. C., no. 278, pp. 305-341.

Weinstein, A. 1918 Coincidence of crossing over in Drosophila melanogaster (ampelophila). Genetics, vol. 3, pp. 135-172. 